\title{
Molecular identification and typing of lactic acid bacteria associated with the production of two artisanal raw milk cheeses
}

\author{
Koenraad VAN HooRdE*, Peter VANDAMME, Geert HUYS \\ Laboratory of Microbiology, Faculty of Sciences, Ghent University, \\ K.L. Ledeganckstraat 35, 9000 Gent, Belgium
}

\begin{abstract}
A polyphasic approach was used to evaluate the diversity and persistence of lactic acid bacteria (LAB) strains during the production and ripening of two Flemish artisanal raw milk Goudatype cheeses, Bellie and Dulses. During two consecutive productions with a one-month interval, samples of milk, starter, curd and cheese at various ripening times were sampled for conventional culturing using four different selective media. The resulting set of 734 isolates was identified using (GTG) $)_{5}$-PCR fingerprinting and sequence analysis of the $16 \mathrm{~S}$ rRNA and pheS genes. Isolated LAB mainly consisted of Lactobacillus paracasei, Lactococcus lactis subsp. lactis, Lactobacillus plantarum, Pediococcus pentosaceus, Lactobacillus brevis, Lactobacillus rhamnosus, Lactobacillus curvatus, Enterococcus faecalis, Enterococcus durans and Lactobacillus perolens. A combined typing approach including (GTG) 5 -PCR and amplified fragment length polymorphism (AFLP) analysis revealed the presence of a Lc. lactis subsp. lactis isolate of the starter in ripened cheese at eight weeks and the persistence of several other LAB strains throughout the two successive production batches. Possibly, a number of these strains are autochthonous members of the microbial cheese production environment that play an important role in the development of the sensory properties of the cheese.
\end{abstract}

artisanal cheese / Gouda / lactic acid bacteria / rep-PCR / AFLP

\begin{abstract}
摘要 - 两种手工生鲜奶干酪中乳酸菌的鉴定和分类。摘要采用多相方法对 Flemish 手工 生鲜奶高达型 Bellie 和 Dulses 干酪生产和成熟过程中乳酸菌的多样性和持久性进行了评 价。在两种干酪的连续生产过程中, 每间隔一个月采样一次, 采集原料乳、发酵剂、凝乳和 不同成熟期的干酪样品,然后使用四种不同的选择性培养基分别对样品进行常规培养。采 用 (GTG) $)_{5}$-PCR 指纹图谱及 $16 \mathrm{~S}$ rRNA 序列分析和 pheS 基因法对 734 株分离菌株进行了鉴 定。分离出的乳酸菌主要有副干酪乳杆菌、乳酸乳球菌乳酸亚种、植物乳杆菌、戊糖片球 菌、短乳杆菌、鼠李糖乳杆菌、弯曲乳杆菌、粪肠球菌、耐久肠球菌和 perolens 乳杆菌。 采用 $(\mathrm{GTG})_{5}$-PCR 和扩增片段长度多态性 (AFLP) 两种方法相结合进行分类, 研究发现在成 熟 8 周的干酪中存在乳酸乳球菌乳酸亚种,通过对两个连续批次产品的分析证明了还存在其 他乳酸菌。其中一些对干酪风味形成和感官特性起着重要作用的乳酸菌可能来源于酪的 生产环境。
\end{abstract}

\section{手工干酪 / 高达干酪 / 乳酸菌 / rep-PCR / AFLP}

\footnotetext{
* Corresponding author (通讯作者): Koenraad.VanHoorde@UGent.be
} 


\begin{abstract}
Résumé - Identification moléculaire et typage des bactéries lactiques associées à la production de deux fromages artisanaux au lait cru. Une analyse basée sur une approche polyphasique a été employée pour évaluer la diversité et la persistance de souches de bactéries lactiques (LAB) pendant la production et l'affinage de deux fromages au lait cru artisanaux flamands de type Gouda, le Bellie et le Dulses. Pendant deux productions consécutives espacées d'un mois, des prélèvements de lait, de présure, de caillé et de fromage à divers stades d'affinage ont été effectués pour mise en culture conventionnelle sur quatre milieux sélectifs. Les 734 isolats obtenus ont été identifiés par $(\mathrm{GTG})_{5}-\mathrm{PCR}$ et séquençage de l'ARNr $16 \mathrm{~S}$ et du gène pheS. Les principales bactéries lactiques isolées appartenaient aux espèces Lactobacillus paracasei, Lactococcus lactis subsp. lactis, Lactobacillus plantarum, Pediococcus pentosaceus, Lactobacillus brevis, Lactobacillus rhamnosus, Lactobacillus curvatus, Enterococcus faecalis, Enterococcus durans et Lactobacillus perolens. Une approche combinée des techniques de (GTG) 5 -PCR et d'analyse du polymorphisme des fragments d'ADN obtenus après amplification restrictive (AFLP) a été appliquée au typage des isolats et a révélé la présence de Lc. lactis subsp. lactis provenant du levain dans le fromage affiné pendant huit semaines, et la persistance de plusieurs autres souches de bactéries lactiques durant deux productions successives. Il est probable que certaines de ces souches soient autochtones de l'environnement de production des fromages et qu'elles jouent un rôle important dans le développement des caractéristiques sensorielles des fromages.
\end{abstract}

\title{
fromage artisanal / Gouda / bactéries lactiques / rep-PCR / AFLP
}

\section{INTRODUCTION}

Gouda is a yellowish semi-hard cheese generally made from bovine milk and represents one of the primary Dutch-type cheese varieties [20]. For flavor development in Gouda-type cheeses, microbial enzyme activity by lactic acid bacteria (LAB) is of utmost importance. Next to the starter, which usually consists of Lactococcus lactis subsp. lactis and Lactococcus lactis subsp. cremoris, sometimes supplemented with citratemetabolizing Lactococcus lactis subsp. lactis (biovar diacetylactis) or Leuconostoc strains [21], non-starter LAB (NSLAB) entering the production process via the milk, the cheese-making equipment and/or the production environment also play an important role in aroma and flavor formation during cheese ripening [8]. The NSLAB population in Dutch-type cheeses is generally dominated by lactobacilli, in particular Lactobacillus paracasei, although members of other LAB genera such as Leuconostoc, Pediococcus and Enterococcus may also occur $[3,15]$. Because NSLAB gradually outcompete the starter to become the dominant microflora in the ripened cheese [8], both the qualitative and quan- titative composition of the NSLAB community are considered to play an important role in the development of the sensorial cheese characteristics. Moreover, organoleptic properties of a cheese are often related to strain-dependent abilities to form specific aroma and flavor compounds [12,22]. Hence, taxonomic characterization of NSLAB populations up to the strain level is important to assess the individual contribution of predominant strain types to the organoleptic profile of the cheese.

A broad range of DNA-based methods is available for identification and typing of LAB isolates [4, 6, 19]. 16S rRNA gene sequencing is one of the most commonly used techniques for identification and classification of LAB species, but fails to discriminate between phylogenetically closely related LAB species or between subspecies [6]. A number of recent studies indicate that alternative gene targets for sequencing such as the RNA polymerase B subunit gene, $r p o B$, and the phenylalanyltRNA synthase gene, pheS, display a higher taxonomic resolution than the $16 \mathrm{~S}$ rRNA gene within several LAB genera [5, 14, 18]. For differentiation at strain level, 
molecular fingerprinting techniques such as repetitive DNA element PCR (rep-PCR) and amplified fragment length polymorphism (AFLP) analysis [19] have been well validated for LAB. Rep-PCR fingerprinting is a straightforward and reproducible method which has been demonstrated to be useful for rapid and reliable differentiation of lactobacilli and other LAB at species, subspecies and potentially strain level $[9,11]$. AFLP, on the other hand, has proven its use as a high-resolution fingerprinting technique for intraspecies identification and genotyping of LAB and bifidobacteria from various fermented food products as well as from the human gastrointestinal flora [1].

In the present study, rep-PCR using the $(\mathrm{GTG})_{5}$-primer and AFLP were used as molecular fingerprinting tools to study the genotypic diversity and persistence of LAB strains throughout successive productions and ripening of two Flemish artisanal raw milk cheeses.

\section{MATERIAL AND METHODS}

\subsection{Characteristics of cheeses under study}

Two Flemish artisanal Gouda-type cheeses, Bellie and Dulses, were analyzed in this study. Both cheeses were produced from the same raw milk batch using a commercial starter culture consisting of a mixture of Lactococcus lactis subsp. lactis, Lactococcus lactis subsp. cremoris and Lactococcus lactis subsp. lactis biovar diacetylactis strains. Both cheeses differ slightly in technological production parameters with regard to curdling and stirring temperature, final temperature of the whey-curd mixture and pressing time. During two independent sampling rounds with a one-month interval, the production of the two cheeses was monitored by collecting samples from the starter, milk, curd and the cheese after 3, 5, 8 and 12 weeks of ripening. From the second production, the curd and one-day-old and one-week-old cheeses were also sampled. Samples were obtained by means of a trier according to the recommendations of the International Commission on Microbiological Specifications for Foods (ICMSF) [10].

\subsection{Sampling and bacteriological analysis}

One $\mathrm{g}$ of cheese was homogenized in $9 \mathrm{~mL} 2 \% \mathrm{w} / \mathrm{v}$ trisodium citrate using a Stomacher Lab-Blender, after which 10 -fold serial dilutions were prepared in peptone physiological solution $(0.1 \%$ w/v bacteriological peptone (L37, OXOID, Basingstoke, UK) and $0.85 \% \mathrm{w} / \mathrm{v} \mathrm{NaCl}$ ). A volume of $0.1 \mathrm{~mL}$ was spread-plated in triplicate on the following media for isolation of LAB: Kanamycin Aesculin Azide Agar Base (KAAAB) (CM0591, OXOID) supplemented with $20 \mathrm{mg} \cdot \mathrm{L}^{-1}$ kanamycin (SR00925, OXOID) for enterococci, Lactobacillus Selection agar (LBS) (211327, BD, New Jersey, USA) for lactobacilli, M17 agar (CM0785, OXOID) supplemented with lactose $(0.5 \%)$ for lactococci and Mayeux, Sandine, Elliker agar (MSE) (401738, Biolife, Milan, Italy) for leuconostocs. KAAA and LM17 were incubated for $48-72 \mathrm{~h}$ at $37{ }^{\circ} \mathrm{C}$ under aerobic conditions. LBS agar plates were incubated at $28{ }^{\circ} \mathrm{C}$ for $48-72 \mathrm{~h}$ under anaerobic conditions and MSE agar plates were aerobically incubated for $7 \mathrm{~d}$ at $28{ }^{\circ} \mathrm{C}$. For each sample and per medium, a maximum of nine colonies were randomly selected from the plated dilutions in the range of 30-300 CFU and purified on MRS agar (CM0359, OXOID) under the appropriate conditions. This way, a total of 734 isolates from two production batches of Bellie and Dulses were recovered for further analysis. 


\subsection{DNA extraction from pure cultures}

For dereplication purposes, all isolates were subjected to a fast alkaline DNA extraction digest resulting in a crude DNA extract. First, a small portion of one colony was suspended in $20 \mu \mathrm{L}$ of lysis buffer ( $5 \% \mathrm{w} / \mathrm{v} \mathrm{NaOH}$ and $0.25 \% \mathrm{w} / \mathrm{v}$ SDS $)$. The cell suspension was subsequently heated at $95{ }^{\circ} \mathrm{C}$ for $15 \mathrm{~min}$ and centrifuged for a few seconds at $13000 \mathrm{rpm}$. After adding $180 \mu \mathrm{L}$ of MQ water, the extract was centrifuged for $5 \mathrm{~min}$ at $13000 \mathrm{rpm}$ and stored at $-20{ }^{\circ} \mathrm{C}$. For identification and typing of the dereplicated set of isolates, a second extraction method according to the slightly modified protocol of Pitcher et al. $[11,16]$ was used to obtain DNA of higher quality and purity. Quality and purity of the DNA extracts were checked spectrophotometrically at 234, 260 and 280 nm (SpectraMax Plus ${ }^{384}$, Molecular Devices, California, USA) and visually by electrophoresis of $8 \mu \mathrm{L}$ DNA mixed with $2 \mu \mathrm{L}$ loading dye (4 $\mathrm{g}$ sucrose and $2.5 \mathrm{mg}$ bromophenol blue dissolved in $6 \mathrm{~mL}$ TE buffer) on a $1 \% \mathrm{w} / \mathrm{v}$ agarose (RESult LE General Purpose Agarose, BIOzym group, Landgraaf, Holland) gel for $30 \mathrm{~min}$ at $100 \mathrm{~V}$ in $1 \mathrm{X}$ TAE buffer $\left(40 \mathrm{mmol} \cdot \mathrm{L}^{-1}\right.$ Tris-acetate, $1 \mathrm{mmol} \cdot \mathrm{L}^{-1}$ EDTA, $\mathrm{pH} 8.0$ ), flanked by a molecular weight marker (SmartLadder, Eurogentec, Seraing, Belgium). The amount of DNA was standardized with $1 \mathrm{X}$ TE buffer $\left(10 \mathrm{mmol} \cdot \mathrm{L}^{-1}\right.$ Tris base, $1 \mathrm{mmol} \cdot \mathrm{L}^{-1}$ EDTA) to a working concentration of $50 \mathrm{ng} \cdot \mu \mathrm{L}^{-1}$.

\subsection{Dereplication and identification of isolates}

For dereplication, crude alkaline DNA extracts of all isolates were subjected to
rep-PCR analysis using the (GTG) 5 -primer as described previously [9]. The resulting fingerprints were analyzed with the BioNumerics software package (upgrade version 4.61, Applied Maths BVBA, SintMartens-Latem, Belgium) and cluster analysis was conducted using the curve-based Pearson product-moment correlation coefficient. Subsets of isolates recovered on a given medium from a given sample type (milk, starter, curd or cheese at different ripening times) collected during a given sampling campaign were included for separate dendrogram construction. In each of these dendrograms, (GTG) $)_{5}$-PCR clusters were delineated based on visual comparison of band patterns and a minimum Pearson similarity coefficient of $90.0 \%$. For each (GTG) ${ }_{5}$-PCR cluster, one or two representative isolates were selected. This way, the initial set of 734 isolates was reduced to a collection of 298 genotypically unique isolates. This selection was subsequently subjected to DNA extraction using an adapted protocol of Pitcher et al. [11, 16] and reanalyzed using $(\mathrm{GTG})_{5}$-PCR. The new $(\mathrm{GTG})_{5}$-PCR profiles were then compared with an inhouse BioNumerics reference database for identification. Isolates were assigned to a given LAB species when they clustered together with one or more type or reference strains of that species. Isolates that could not be identified unambiguously by (GTG) $)_{5}$-PCR were subjected to partial 16S rRNA and/or pheS gene sequencing [18]. To determine their closest relatives, partial 16S rRNA gene sequences of unknown species were compared with the EMBL nucleotide sequence database using the BLAST algorithm. Newly determined pheS sequences were imported into BioNumerics and aligned and compared with a user-generated database containing the pheS sequences of type and reference strains (BCCM/LMG Bacteria Collection, Ghent University, Belgium, http:// bccm.belspo.be) [18]. 


\subsection{Typing of LAB}

Both (GTG) ${ }_{5}$-PCR and AFLP analysis were used for typing of LAB isolates. First, a dendrogram comprising the (GTG) $)_{5}$-profiles of the selected 298 isolates was constructed, which resulted in the delineation of 25 clusters, all together comprising 244 isolates. Delineation of the clusters occurred at a minimum similarity percentage of $75.0 \%$ and was supported by visual inspection of the band pattern similarity. The remaining 54 isolates did not group into any of these clusters. To reduce the number of isolates for AFLP typing, each of the 25 main clusters was screened for the presence of isolates recovered from both cheeses and/or during the two sampling campaigns. From each of these clusters, 2-3 representative isolates were selected for AFLP analysis in such a way that both batches and if possible both cheeses were enclosed. This resulted in a total of 31 isolates which were subsequently subjected to AFLP analysis as described previously [17] for discrimination at strain level using the primer pair E01/T01. Similarity among digitized AFLP patterns was assessed using the Unweighted Pair Group Method with Arithmetic mean (UPGMA) for clustering and the Pearson product-moment correlation coefficient. Finally, genotype relatedness between the selected isolates was determined by creating a composite dataset from both profile types from which an averaged similarity matrix and UPGMA dendrogram were constructed.

\section{RESULTS}

\subsection{Sampling and enumeration of LAB}

Two subsequent productions of two Flemish artisanal raw milk cheeses made from the same milk batch were sampled with a one-month interval and subjected to LAB culturing using four different selective media. Enumeration data of LAB on the different media are shown in Table I. For the two milk samples, bacterial counts ranged from $1.00 \mathrm{log} \mathrm{CFU} \cdot \mathrm{mL}^{-1}$ on LBS agar to $2.88 \log \mathrm{CFU} \cdot \mathrm{mL}^{-1}$ on LM17 agar, where the highest counts were observed. The starter showed no growth on KAAA and LBS but reached counts of up to $10.33 \log$ CFU.g ${ }^{-1}$ on LM17. For both cheeses, counts on KAAA and LBS displayed a strong increase during the first five to eight weeks of ripening, whereas LM17 and MSE showed high numbers already from the curd on. In general, all cheeses showed a similar evolution in counts on all the four media.

\subsection{Identification of $\mathrm{LAB}$ isolates}

A polyphasic approach was used for identification of the isolates. For dereplication, (GTG) $)_{5}$-PCR fingerprinting was performed on the crude alkaline DNA extract of all 734 isolates selected from the four isolation media used. Clustering and dereplication reduced this set to 298 unique isolates which were subjected to a second DNA extraction and which were reanalyzed with (GTG) ${ }_{5}^{-}$ PCR to produce high-quality DNA fingerprints. These profiles were then compared with an in-house BioNumerics database for identification, and isolates remaining unidentified at this stage were subjected to partial $16 \mathrm{~S}$ rRNA and/or pheS gene sequencing. Based on this polyphasic identification approach, all isolates were mainly assigned to Lactobacillus paracasei, Lactococcus lactis subsp. lactis, Lactobacillus plantarum, Pediococcus pentosaceus, Lactobacillus brevis, Lactobacillus rhamnosus, Lactobacillus curvatus, Enterococcus faecalis, Enterococcus durans and Lactobacillus perolens. Other LAB taxa occasionally retrieved 


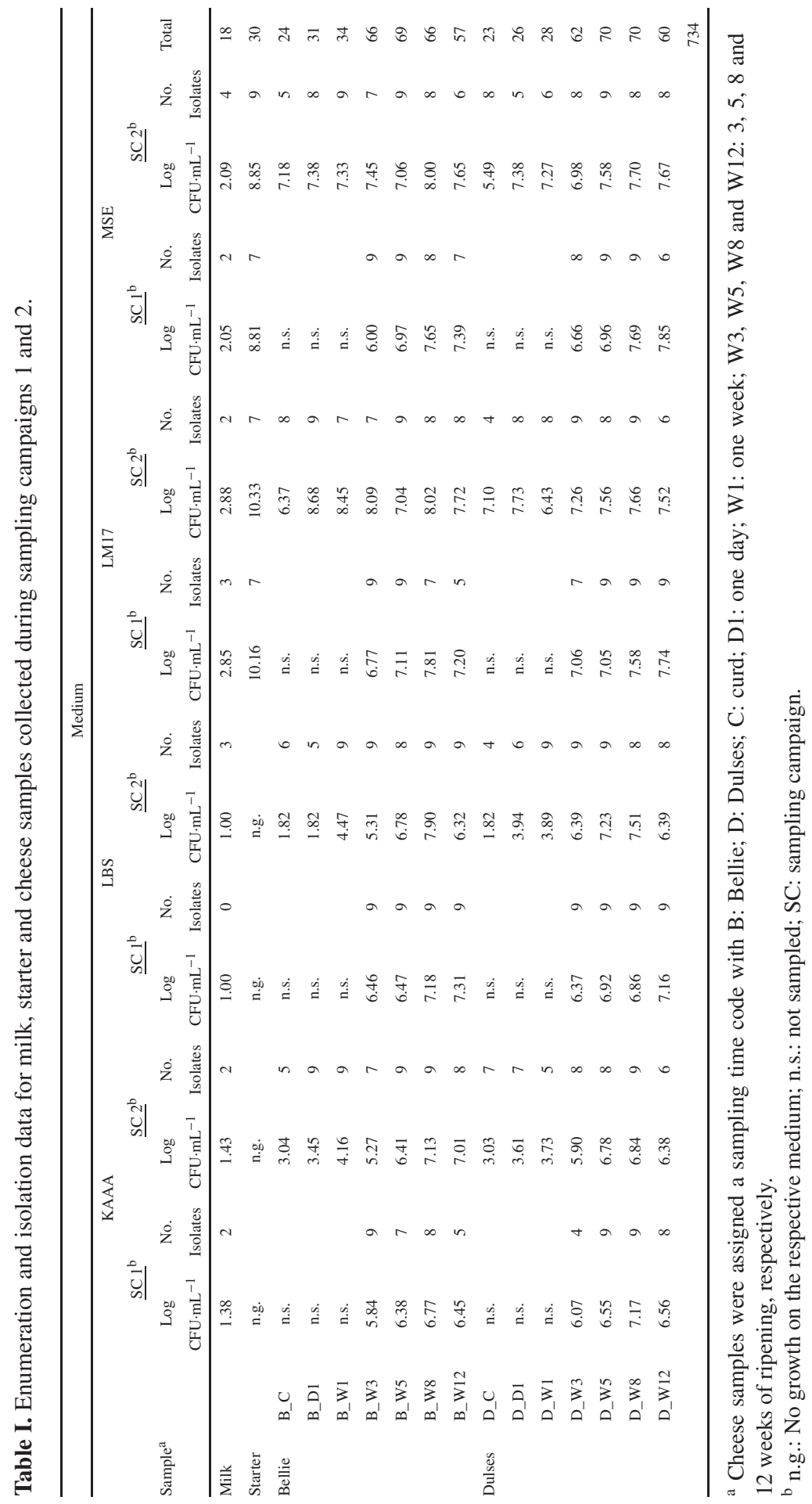


(less than 1.0\%) included Lactococcus raffinolactis, Lactobacillus parabuchneri, Leuconostoc lactis, Leuconostoc mesenteroides, Lactobacillus sakei, Enterococcus casseliflavus and Weissella sp.

\subsection{Typing of LAB isolates}

Based on $(\mathrm{GTG})_{5}$-PCR, the selected 298 isolates grouped into 25 main clusters along with a series of smaller clusters of species which made up less than $1.0 \%$ of the total number of isolates and with unclustered isolates exhibiting unique profiles. Clusters of isolates belonging to common species are listed in Table II. The two species showing the highest strain diversity were $L b$. paracase $i$ and $P$. pentosaceus, being represented by 9 and 7 different clusters, respectively. Each of the 25 main clusters was screened for the presence of isolates recovered from both cheeses during the two sampling campaigns. For $P$. pentosaceus and $L b$. paracasei, three and five different clusters, respectively, harbored isolates from both sampling campaigns, sometimes across both cheese types. For Lb. perolens, Lb. rhamnosus, Lb. plantarum, Lb. brevis, Lb. curvatus and Lc. lactis subsp. lactis, one cluster each also contained isolates from both sampling rounds and/or both cheese types. From each of these clusters, 2-3 representative isolates enclosing both batches and if possible both cheeses were selected for AFLP analysis. This resulted in a selection of 31 isolates encompassing 14 (GTG) $)_{5}$-PCR clusters harboring unique profiles belonging to eight species. The corresponding AFLP profiles grouped according to species with similarity values for the discrete clusters of isolates ranging from $74.9 \%$ to $98.2 \%$. Figure 1 shows the UPGMA dendrogram obtained from the averaged similarity matrix of the combined (GTG) ${ }_{5}-\mathrm{PCR}$ and AFLP fingerprint types. Reproducibility was assessed by three repeated (GTG) ${ }_{5}{ }^{-}$
PCR and AFLP analyses of Lb. plantarum LMG $6907^{T}$.

Composite profiles of LMG $6907^{T}$ clustered at $90.0 \%$ using the Pearson productmoment correlation coefficient, and this value was set as the minimum percentage of similarity for isolates to represent the same genotypic strain type. This way, eight clusters with similarities $\geqslant 90.0 \%$ were recognized in the species $L b$. brevis (Lb1, 92.7\%) Lb. curvatus (Lb2, 94.0\%), Lb. perolens (Lb3, 93.3\%), Lb. paracasei (Lb5, 97.1\% and Lb8, 97.7\%), Lb. rhamnosus (Lb9, 94.6\%), Lb. plantarum (Lb10, 93.0\%) and Lc. lactis subsp. lactis (Lc1, 91.9).

\section{DISCUSSION}

Several factors, including feed and milk composition, the traditional cheesemaking practice and the production environment, can influence the diversity and dynamics of microbial communities associated with the production of artisanal cheeses and thus may affect the typical organoleptic properties of the end product $[7,13]$. As cheese quality is largely determined by the metabolic activities of $\mathrm{LAB}$ that dominate during cheese ripening, it is important to taxonomically characterize individual strains that potentially contribute to the aroma and body of the cheese.

Although (GTG) $)_{5}$-PCR fingerprinting has proven to be a useful tool for differentiating LAB at species, subspecies and up to strain level [9], a combined approach also including high-resolution AFLP analysis was employed for strain typing. The resulting composite fingerprinting analysis revealed the presence of eight clusters containing genotypically indistinguishable isolates recovered from different cheese types and/or production batches. These findings allow us to speculate on the persistence of certain strain types during the cheese production process or during successive productions. For instance, indistinguishable (GTG) $5_{5}$ PCR and AFLP 


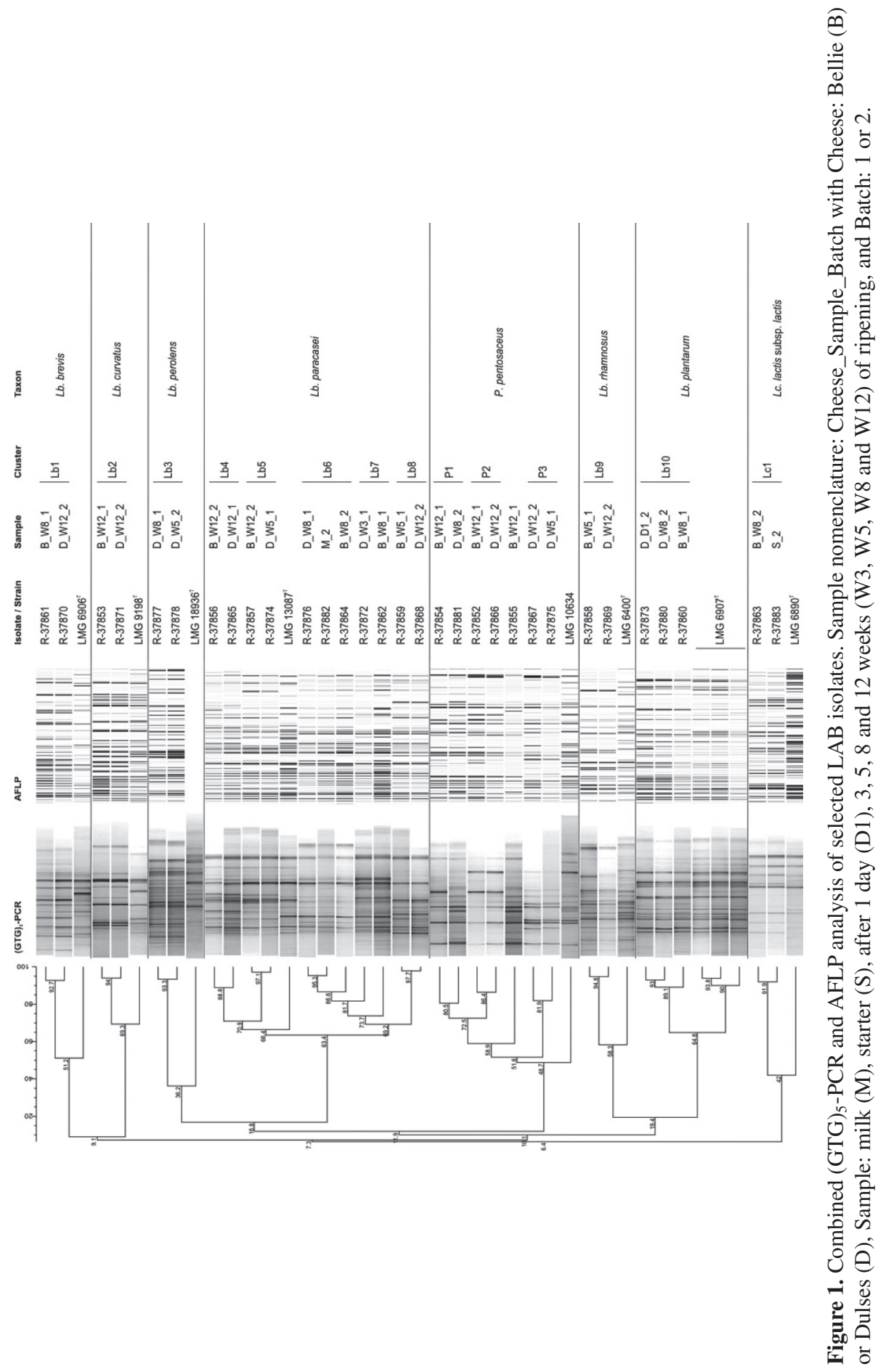


Table II. Predominant species and strain diversity during ripening as determined by $(\mathrm{GTG})_{5}$-PCR fingerprinting.

\begin{tabular}{lccc}
\hline Species & $\begin{array}{c}\text { Number of } \\
\text { isolates }\end{array}$ & Frequency & $\begin{array}{c}\text { Number of } \\
\text { clusters }^{\mathrm{b}}\end{array}$ \\
\hline Lactobacillus paracasei & 255 & $34.7 \%$ & 9 \\
Lactococcus lactis subsp. lactis & 195 & $26.6 \%$ & 1 \\
Lactobacillus plantarum & 77 & $10.5 \%$ & 1 \\
Pediococcus pentosaceus & 55 & $7.5 \%$ & 7 \\
Lactobacillus brevis & 28 & $3.8 \%$ & 1 \\
Lactobacillus rhamnosus & 17 & $2.3 \%$ & 1 \\
Lactobacillus curvatus & 15 & $2.0 \%$ & 1 \\
Enterococcus faecalis & 13 & $1.8 \%$ & 2 \\
Enterococcus durans & 12 & $1.6 \%$ & 1 \\
Lactobacillus perolens & 8 & $1.1 \%$ & 1 \\
Total & 675 & $91.9 \%$ & 25 \\
\hline
\end{tabular}

${ }^{\text {a }}$ Species representing more than $1 \%$ of the total number of 734 isolates.

${ }^{\mathrm{b}}$ Clusters were delineated by visual comparison of $(\mathrm{GTG})_{5}$-fingerprints and a minimum Pearson similarity coefficient of $75.0 \%$.

profiles were obtained in cluster Lc1 for Lc. lactis subsp. lactis isolates retrieved in the ripened Bellie cheese at week 8 (B_W8_2) and from the starter used (S_2) (Fig. 1, cluster Lc1). In contrast to what is generally assumed [8], this observation indicates that some members of the starter population are not entirely outcompeted during the ripening process. In several clusters, the same strain type was retrieved in both cheese types during the two sampling campaigns with a one-month interval, as was the case for clusters Lb1, Lb2, $\mathrm{Lb} 5, \mathrm{Lb} 8$ and Lb9. On the other hand, cluster Lb3 consisted of isolates retrieved only from Dulses cheese over both productions. This suggests that some of the predominant species like $L b$. paracase $i$ were represented by the same strain types in two consecutive population batches irrespective of the milk source, variations in environmental conditions or differences in production parameters for both cheeses. Clustering of $\mathrm{Lb}$. plantarum isolates in cluster Lb10 retrieved from one-day-old and 8-weekold Dulses of the second production batch (D_D1_2 and D_W8_2) demonstrates the succession of this strain type during the ripening of that cheese. Noteworthy, the clustering of a third isolate from Bellie of the first production (B_W8_1) at $89.9 \%$ similarity also suggests the prevalence of this strain type over both productions of both cheese types.

Possibly, some of the persistent strains are introduced in the cheese-making process through the milk. Isolates of $L b$. paracasei cluster Lb6 were retrieved from the second milk batch, M_2, as well as from 8-week-old ripened Dulses cheese sampled during the first production round (D_W8_1), and despite clustering at $\leq 90.0 \%$ similarity, were possibly also present in Bellie of the second production batch (B_W8_2). However, additional sampling and microbial analysis of the milking equipment and milk storage tanks is required to substantiate this hypothesis. On the other hand, it cannot be excluded that certain strain types able to colonize and persist on surfaces of the cheese-making equipment are being introduced into the process by the cheese manufacturer, or circulate in the air of the production and ripening facility. 


\section{CONCLUSIONS}

Although the criteria for selection of potential adjuncts are not strictly defined, taxonomically well-characterized isolates from good-quality aged cheeses with a high quality aroma may be suitable candidates. In this context, the ability to reach and maintain high numbers during ripening has been considered as another important criterion for NSLAB to be an appropriate adjunct culture [2]. This study revealed the presence of Lc. lactis subsp. lactis isolates of the starter in cheese ripened for eight weeks and the persistence of several strains belonging to the predominant NSLAB throughout two successive production batches of two artisanal raw milk Gouda-type cheeses. Some of these prevailing strain types may be used in the screening for potential adjunct cultures and such analyses should certainly address the contribution of these strains to the development of the sensory profile of the cheeses.

Acknowledgements: This research was supported by the Institute for the Promotion of Innovation through Science and Technology in Flanders (IWT-Vlaanderen). The fund for Scientific Research-Flanders (FWO-Flanders) is acknowledged for the postdoctoral fellowship of G. Huys. We would also like to thank the cheese manufacture workers for providing the samples used in this study.

\section{REFERENCES}

[1] Ben Amor K., Vaughan E.E., de Vos W.M., Advanced molecular tools for the identification of lactic acid bacteria, J. Nutr. 137 (2007) 741S-747S.

[2] Briggiler-Marco M., Capra M.L., Quiberoni A., Vinderola G., Reinheimer J.A., Hynes E., Nonstarter Lactobacillus strains as adjunct cultures for cheese making: In vitro characterization and performance in two model cheeses, J. Dairy Sci. 90 (2007) 4532-4542.

[3] Christiansen P., Petersen M.H., Kask S., Moller P.L., Petersen M., Nielsen E.W.,
Vogensen F.K., Ardo Y., Anticlostridial activity of Lactobacillus isolated from semihard cheeses, Int. Dairy J. 15 (2005) 901909.

[4] Coeuret V., Dubernet S., Bernardeau M., Gueguen M., Vernoux J.P., Isolation, characterisation and identification of lactobacilli focusing mainly on cheeses and other dairy products, Lait 83 (2003) 269-306.

[5] De Bruyne K., Schillinger U., Caroline L., Boehringer B., Cleenwerck I., Vancanneyt M., De Vuyst L., Franz C.M.A.P., Vandamme P., Leuconostoc holzapfelii sp. nov., isolated from Ethiopian coffee fermentation and assessment of sequence analysis of housekeeping genes for delineation of Leuconostoc species, Int. J. Syst. Evol. Microbiol. 57 (2007) 2952-2959.

[6] Dellaglio F., Felis G.E., Taxonomy of lactobacilli and bifidobacteria, in: Tannock G.W. (Ed.), Probiotics and Prebiotics: Scientific Aspects, Caister Academic Press, Wymondham, UK, 2005, pp. 25-50.

[7] Fortina M.G., Ricci G., Acquati A., Zeppa G., Gandini A., Manachini P.L., Genetic characterization of some lactic acid bacteria occurring in an artisanal protected denomination origin (PDO) Italian cheese, the Toma piemontese, Food Microbiol. 20 (2003) 397404.

[8] Fox P.F., McSweeney P.L.H., Lynch C.M., Significance of non-starter lactic acid bacteria in Cheddar cheese, Aust. J. Dairy Technol. 53 (1998) 83-89.

[9] Gevers D., Huys G., Swings J., Applicability of rep-PCR fingerprinting for identification of Lactobacillus species, FEMS Microbiol. Lett. 205 (2001) 31-36.

[10] ICMSF, Microorganisms in foods 2. Sampling for microbiological analysis: principles and specific applications, University of Toronto Press, Toronto, 1986.

[11] Masco L., Huys G., Gevers D., Verbrugghen L., Swings J., Identification of Bifidobacterium species using rep-PCR fingerprinting, Syst. Appl. Microbiol. 26 (2003) 557-563.

[12] Mauriello G., Moio L., Moschetti G., Piombino P., Addeo F., Coppola S., Characterization of lactic acid bacteria strains on the basis of neutral volatile compounds produced in whey, J. Appl. Microbiol. 90 (2001) 928-942.

[13] Moatsou G., Kandarakis I., Moschopoulou E., Anifantakis E., Alichanidis E., Effect of 
technological parameters on the characteristics of kasseri cheese made from raw or pasteurized ewes' milk, Int. J. Dairy Technol. 54 (2001) 69-77.

[14] Naser S.M., Dawyndt P., Hoste B., Gevers D., Vandemeulebroecke K., Cleenwerck I., Vancanneyt M., Swings J., Identification of lactobacilli by pheS and rpoA gene sequence analyses, Int. J. Syst. Evol. Microbiol. 57 (2007) 2777-2789.

[15] Østlie H.M., Eliassen L., Florvaag A., Skeie S., Phenotypic and PCR-based characterization of the microflora in Norvegia cheese during ripening, Int. J. Food Microbiol. 94 (2004) 287-299.

[16] Pitcher D.G., Saunders N.A., Owen R.J., Rapid extraction of bacterial genomic DNA with guanidinium thiocyanate, Lett. Appl. Microbiol. 8 (1989) 151-156.

[17] Scheirlinck I., Van der Meulen R., Van Schoor A., Cleenwerck I., Huys G., Vandamme P., De Vuyst L., Vancanneyt M., Lactobacillus namurensis sp. nov., isolated from a traditional Belgian sourdough, Int. J. Syst. Evol. Microbiol. 57 (2007) 223-227.
[18] Scheirlinck I., Van der Meulen R., Van Schoor A., Vancanneyt M., De Vuyst L., Vandamme P., Huys G., Influence of geographical origin and flour type on diversity of lactic acid bacteria in traditional Belgian sourdoughs, Appl. Environ. Microbiol. 73 (2007) 6262-6269.

[19] Temmerman R., Huys G., Swings J., Identification of lactic acid bacteria: culturedependent and culture-independent methods, Trends Food Sci. Technol. 15 (2004) 348359.

[20] Van den Berg G., CHEESES/Dutch-type cheeses, in: Caballero B., Trugo L.C., Finglas P.M. (Eds.), Encyclopedia of Food Sciences and Nutrition, Academic Press, Oxford, 2003, pp. 1129-1135.

[21] Walstra P., Noomen A., Geurts T.J., Dutchtype varieties, in: Fox P.F. (Ed.), Cheese: Chemistry, Physics and Microbiology, Chapman and Hall, London, 1993, pp. 3982.

[22] Yvon M., Rijnen L., Cheese flavour formation by amino acid catabolism, Int. Dairy J. 11 (2001) 185-201. 